\title{
Perbandingan Efektifitas Mikroorganisme Lokal Nanas dan Batang Pisang terhadap Pertumbuhan Tanaman Jagung Manis di Wamena
}

\section{Comparison of the Effectiveness Local Microorganism of Pineapple and Banana Pseudostem on Growth of Sweet Corn in Wamena}

\section{Sumiyati Tuhuteru*, Rein Edward Yohanes Rumbiak, Patras Pumoko, Tinus Kossay, dan Yuna Yikwa}

Sekolah Tinggi Ilmu Pertanian Petra Baliem Wamena

Jl. Sanger, Potikelek, Wamena, Papua 99511, Indonesia

Diterima 20 Juli 2021/Disetujui 29 Oktober 2021

\begin{abstract}
Types of nutrient sources other than from fertilizers that are known in general can also be sourced from the use of local microorganisms made from fruit, pineapple, vegetable or banana pseudo stem waste. The study aimed to compare the effectiveness of local microorganisms from pineapple and banana waste on sweet corn cultivation. The study consisted of two separate experiments, namely application of local microorganism pineapple and application of banana waste local microorganism. Each experiment used a completely randomized design consisting of 5 levels of local microorganism concentration, namely control (without local microorganism), concentration of $100 \mathrm{~mL} \mathrm{~L} \mathrm{~L}^{-1}, 150 \mathrm{~mL} \mathrm{~L} \mathrm{~L}^{-1}, 200 \mathrm{~mL} \mathrm{~L}^{-1}$ and

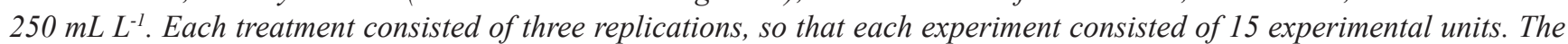
results showed the effectiveness of local microorganism from banana waste is better compared to local microorganism from pineapple as indicated by the of plant height, root dry weight, leaf area, relative growth of plant and corn ear without husk at 8 WAP.
\end{abstract}

Keywords: organic fertilizer, plant nutrients, plant productivity, waste

ABSTRAK

Jenis sumber hara selain bersumber dari pupuk yang telah dikenal secara umum, juga dapat bersumber dari pemanfaatan mikroorganisme lokal yang dibuat dari limbah buah, nanas, sayur ataupun batang pisang. Penelitian bertujuan untuk mengetahui perbandingan efektivitas penggunaan MOL nanas dan batang pisang pada budidaya jagung manis di Wamena. Penelitian terdiri dari dua percobaan yang dilakukan terpisah yaitu aplikasi MOL nanas dan aplikasi MOL batang pisang. Masing-masing percobaan menggunakan rancangan acak lengkap (RAL) yang terdiri dari 5 taraf konsentrasi MOL, yaitu kontrol (tanpa MOL), konsentrasi $100 \mathrm{~mL} \mathrm{~L} \mathrm{~L}^{-1}, 150 \mathrm{~mL} \mathrm{~L} \mathrm{~L}^{-1}, 200 \mathrm{~mL} \mathrm{~L} \mathrm{~L}^{-1}$ dan $250 \mathrm{~mL} \mathrm{~L}^{-1}$. Masing-masing perlakuan terdiri dari tiga ulangan sehingga setiap percobaan terdiri atas 15 satuan percobaan. Hasil penelitian menunjukkan efektivitas penggunaan MOL batang pisang dibandingkan MOL nanas, yang ditunjukkan pada tinggi tanaman, berat kering akar, luas daun dan laju pertumbuhan nisbi serta bobot segar tongkol jagung manis tanpa kelobot pengamatan 8 MST.

Kata kunci: hara tanaman, limbah, produktivitas tanaman, pupuk organik

\section{PENDAHULUAN}

Di Indonesia, jagung manis menjadi bahan pangan penting karena rasa manisnya akibat adanya kandungan karbohidrat, dibanding jagung pada umumnya (Wahyudi et al., 2012). Waktu konsumsinya saat masih segar dan muda, karena jika terlambat dipanen maka rasa dan kualitasnya akan berubah (Pradipta et al., 2014). Tananam jagung manis dapat menyelesaikan siklus hidupnya di berbagai tempat dengan jenis tanah yang berbeda termasuk lahan

\footnotetext{
* Penulis untuk korespondensi. e-mail: tuhuteru.umy@gmail.com
}

rawa seperti yang ada di Wamena. Selain itu, kenyataan dilapangan ditemukannya masalah dalam praktek usaha tani jagung manis yang dilakukan petani masih mengalami kendala seperti pengadaan benih yang masih terbatas, teknik perawatan tanaman, teknik pemanenan, penanganan setelah panen, dan minimnya kapabilitas lahan (Amin, 2015). Hal ini disebabkan akibat karena praktek budidaya yang diterapkan di Wamena sejauh ini masih bersifat sistem pertanian organik tradisional, yang teknis budidaya tanamannya belum memanfaatkan pupuk.

Salah satu yang perlu mendapatkan perhatian dalam usaha tani jagung manis adalah produktivitas lahan, karena 
berperan penting dalam mencapai keberhasilan penanaman. Beragam cara dilakukan agar dapat meningkatkan produktivitas lahan (Susi et al., 2018). Produktivitas tanah merupakan gambaran kapabilitas suatu tanah dalam berproduksi menghasilkan tanaman yang tumbuh pada tanah tersebut. Hasil dari tanaman tersebut terdiri atas pertumbuhan dan perkembangan hingga produksi yang dihasilkan. Untuk itu tanah harus diberi pupuk agar mencapai tujuan penanaman (Tuhuteru, 2018).

Penambahan pupuk ke tanah maupun tanaman harus berpedoman pada peraturan penggunaan pupuk yang efektifitas dan efesiensi dari pupuk yang diberikan, baik pupuk kimia maupun pupuk organik. Ketelitian penentuan macam pupuk dipertimbangankan prosedur teknisnya, pemahaman teknis terkait fisiologis tanaman, karakter pupuk dan tanah, lokasi pupuk yang diterapkan sangat menentukan taraf pendayagunaan pupuk tersebut (Tuhuteru, 2018). Jenis sumber hara selain bersumber dari pupuk yang telah dikenal secara umum, juga dapat bersumber dari pemanfaatan mikroorganisme lokal yang dibuat dari limbah buah, nanas, sayur ataupun batang pisang.

Penggunaan limbah alami dengan baik mampu memangkas tingkat kontaminasi lingkungan dan memperbaiki tekstur tanah atau dapat meningkatkan kapabilitas tanah (Mahanani et al., 2020). Seperti penggunaan mikroorganisme lokal (MOL) berbahan dasar buah nanas dan batang pisang yang telah banyak dilakukan. Buah nanas pada umumnya digunakan di tingkat rumah sebagai buah pencuci mulut bahkan bahan pembuat selai dan bagian kulitnya dapat dijadikan limbah organik. Batang pisang dapat dimanfaatkan sebagai bahan pembuat mikroorganisme lokal yang dapat meningkatkan kesuburan tanah (Inrianti et al., 2019).

Proses pembuatan mikroorganisme lokal pada umumnya ditambahkan air leri (air bekas cucian beras) sebagai sumber karbohidrat bagi pertumbuhan mikroorganisme selama proses fermentasi berlangsung. Air leri dikenal sebagai bahan natural yang didapat dari pembuangan sampah rumah tangga saat pencucian beras dan diakui tidak bernilai ekonomis (Lalla, 2018). Untuk itu, upaya yang dapat dilakukan dalam memaksimalkan produksi tanaman seperti tanaman jagung manis di Wamena adalah penataan kembali sistem budidaya pertanian organik yang sejauh ini dilaksanakan melalui penggunaan jenis mikroorganisme lokal hasil fermentasi buah nanas dan batang pisang yang dicampur dengan air bekas cucian beras. Penggunaannya ke tanah dapat meningkatkan produktivitas tanah maupun tanaman dan digunakan dalam bentuk larutan yang dikenal dengan nama larutan MOL (Inrianti et al., 2019).

Peran MOL selain sebagai dasar komponen pupuk yang bermanfaat bagi tanaman juga bermanfaat sebagai agen dekomposer bahan organik, limbah pertanian, limbah rumah tangga dan industri (Manullang et al., 2017). MOL adalah larutan hasil fermentasi yang berbahan dasar dari berbagai sumber daya yang tersedia di alam seperti batang pisang, buah-buahan, sampah rumah tangga, sayuran, maja, lamtoro dan sebagainya telah tersedia setempat dan mengandung unsur hara mikro dan makro serta mengandung bakteri yang berpotensi sebagai perombak bahan organik, perangsang pertumbuhan dan sebagai agen pengendali hama dan penyakit tanaman. Untuk itu, MOL dapat digunakan baik sebagai dekomposer, pupuk hayati dan sebagai pestisida organik terutama sebagai fungisida. Larutan MOL dibuat sangat sederhana yaitu dengan memanfaatkan limbah dari rumah tangga atau tanaman di sekitar lingkungan misalnya sisa-sisa tanaman seperti bonggol pisang, buah nanas, jerami padi, sisa sayuran, nasi basi dan lain-lain (Kurniawan, 2018; Rahmawati et al., 2019).

Pemanfaatan mikroorganisme lokal (MOL) mempunyai keuntungan dari segi biaya yang relatif murah dan kemudahan aplikasinya merupakan pilihan yang telah diterapkan oleh beberapa petani di beberapa daerah (Saputra et al., 2019). Pemanfaatan tersebut disebabkan adanya kandungan mikroba yang bermanfaat bagi pertumbuhan tanaman maupun produktivitas lahan, seperti Lactobacillus, Actinomycetes, pelarut Fosfat dan Saccharomyces (Kuneapah, 2008). Peran utama dari kelompok mikroba tersebut adalah sebagai penyedia unsur hara seperti penambat $\mathrm{N}_{2}$ dari udara, pelarut $\mathrm{P}$ dan hara yang lain. Selain sebagai penyedia hara sebagai fungsi utama, juga mempunyai kemampuan sebagai pemacu pertumbuhan tanaman dengan mensintesis berbagai zat pengatur tumbuh (fitohormon: giberilin, sitokinin, auksin dan inhibitor), serta sebagai pengendali patogen yang berasal dari tanah dengan mengubah gula pada limbah sayuran, buahan atau nasi terutama menjadi asam laktat (Sahwan et al., 2011; Utama et al., 2013).

Dilihat dari peran jenis mikroba yang terkandung dalam larutan MOL dan melihat kondisi sistem pertanian organik yang diterapkan petani Wamena yang belum dilaksanakan sebagaimana teknis sistem pertanian organik yang sesungguhnya, maka peneliti berinisiatif melakukan penelitian ini dengan tujuan untuk mengetahui efektivitas penggunaan MOL nanas dan batang pisang terhadap produktivitas tanaman jagung manis di Wamena yang hasilnya dapat direkomendasikan dalam sistem budidaya petani setempat.

\section{BAHAN DAN METODE}

Pelaksanaan penelitian di bulan Februari hingga Mei 2021 di lahan milik Gereja Advent Wamena Kota, Kabupaten Jayawijaya, Provinsi Papua dengan ketinggian wilayah $1.800 \mathrm{mdpl}$.

\section{Pembuatan Mikro Organisme Lokal (MOL)}

Tahapan pembuatan masing-masing mikroorganisme lokal:

\section{a. MOL nanas}

Pembuatan MOL nanas dimulai dari: sebanyak $5 \mathrm{~kg}$ buah nanas matang yang telah di cincang dan di iris, baik kulit maupun daging buahnya dan diblender kemudian dimasukkan ke ember, tambahkan $2 \mathrm{~kg}$ hasil irisan gula merah, kemudian tambahkan $10 \mathrm{~L}$ air cucian beras pertama. 
Selanjutnya, diaduk hingga bahan-bahan tercampur rata. Kemudian ember ditutup dan disimpan \pm 3 minggu sebelum diaplikasikan ke tanaman. Selanjutnya, diambil sesuai takaran perlakuan yang telah ditetapkan. Dalam proses penyimpanan tidak lupa untuk membuka ember yang berisi MOL sekali sehari, hal ini bertujuan agar udara dapat masuk kedalam ember tersebut dan menghindari terjadinya penumpukan gas.

\section{b. MOL Batang Pisang}

Tahapan pembuatannya adalah: sebanyak $5 \mathrm{~kg}$ batang pisang yang telah dicincang halus, diblender dan dimasukkan dalam wadah yang telah disiapkan. Gula merah sebanyak 2 kg yang telah diiris, kemudian tambahkan $10 \mathrm{~L}$ air cucian beras pertama dicampur dalam wadah yang berisi batang pisang. Seluruh bahan diaduk hingga tercampur rata. Ember ditutup dan disimpan 3 minggu sebelum diaplikasikan ke tanaman. Selanjutnya, diambil sesuai takaran perlakuan yang ditetapkan. Dalam proses penyimpanan tidak lupa untuk membuka ember yang berisi MOL sekali sehari, hal ini bertujuan untuk udara yang masuk kedalam ember tersebut dan menghindari terjadinya penumpukan gas.

Setelah 3 minggu penyimpanan, aplikasi masingmasing MOL yang telah siap ke lahan (saat pembukaan lahan) bersamaan dengan pemberian pupuk kandang sapi sebagai pupuk dasar. Aplikasi selanjutnya pada minggu ke 3 dan 5 minggu setelah tanam (MST).

\section{Pembukaan Lahan}

Pengolahan lahan dilakukan dengan cara menggemburkan tanah, kemudian dibuat bedengan dengan ukuran $2 \mathrm{~m}$ x $3 \mathrm{~m}$ dengan jarak antar bedeng adalah $1 \mathrm{~m}$. Pada bedengan yang telah dibentuk kemudian diberikan campuran pupuk dasar dan MOL sebelum penanaman.

Penanaman dilakukan dengan jarak tanam $60 \mathrm{~cm} \mathrm{x}$ $60 \mathrm{~cm}$ dengan 2 benih per lubang tanam. Setelah ditanam, proses pemeliharaan tanaman dilakukan melalui penyiraman dengan intensitas sekali sehari pada pagi atau sore hari, penyiangan dengan mencabut gulma dan pencegahan serangan OPT masih secara alami (tanpa penggunaan pestisida) karena sistem pertanian yang diterapkan bersifat pertanian organik tradisional (tidak ada input apapun).

\section{Aplikasi MOL}

Pemberian MOL kedua dan ketiga yaitu pada 3 dan 5 MST, setelah pemberian di awal tanam. Aplikasi MOL dengan cara menyiramkan di perakaran tanaman pada masing-masing bedengan berdasarkan perlakuan yang ditetapkan.

Pengukuran peubah dalam penelitian terdiri atas peubah pertumbuhan dan produksi tanaman. Peubah pertumbuhan berupa tinggi tanaman, berat kering daun dan akar, panjang dan luas akar, luas daun, laju pertumbuhan nisbi, serta analisis jumlah klorofil total. Peubah produksi tanaman yang diamati adalah bobot segar tongkol tanpa kelobot per perlakuan.

\section{Rancangan Penelitian}

Penelitian terdiri dari dua percobaan yang dilakukan terpisah yaitu aplikasi MOL nanas dan aplikasi MOL batang pisang. Masing-masing percobaan menggunakan rancangan acak lengkap (RAL) yang terdiri dari 5 taraf konsentrasi MOL, yaitu kontrol (tanpa MOL), konsentrasi $100 \mathrm{~mL} \mathrm{~L}^{-1}, 150 \mathrm{~mL} \mathrm{~L}^{-1}, 200 \mathrm{~mL} \mathrm{~L}^{-1}$, dan $250 \mathrm{~mL} \mathrm{~L}^{-1}$ yang diberikan per unit percobaan per bedengan. Per tanaman jagung diberikan perlakuan sebanyak \pm 3-5.2 L sampai panen, yang pemberiannya dimulai di awal penanaman dilakukan, kemudian pada minggu ke 3 dan 5 setelah tanam, sehingga total pemberian perlakuan MOL adalah sebanyak 3 kali selama proses penanaman berlangsung. Masingmasing perlakuan terdiri dari tiga ulangan, sehingga setiap percobaan terdiri atas 15 satuan percobaan. Selanjutnya, dilakukan analisis melalui uji simultan dan uji DMRT (Duncan's multiple range test) pada taraf 5\%.

\section{HASIL DAN PEMBAHASAN}

\section{Analisis Pertumbuhan}

Pengamatan tinggi jagung manis dilakukan saat umur 3 dan 7 MST menunjukkan perlakuan MOL nanas tidak berpengaruh nyata, dibanding perlakuan MOL batang pisang. Terlihat rata-rata pengukuran tinggi tanaman tertinggi pada 7 MST ditunjukkan oleh perlakuan $200 \mathrm{~mL} \mathrm{~L}^{-1} \mathrm{MOL}$ dengan rata-rata tinggi tanaman sebesar $185.60 \mathrm{~cm}$ (Tabel 1). Meski perlakuan tersebut tidak berbeda nyata dengan perlakuan kontrol.

Secara statistik nilai rata-rata yang ditunjukkan diduga karena pengaruh mikroorganisme lokal berbahan dasar batang pisang jelas sebagai salah satu pemasok nutrisi ke tanaman terutama dalam optimalisasi di fase awal tanaman dan memiliki toleransi atas komplikasi pada tanaman melalui penyediaan nutrisi yang dibutuhkan tanaman (Inrianti et al., 2019). Nutrisi tersebut adalah faktor penentu dalam meningkatkan produktivitas tanaman, seperti kandungan hara makro yang terkandung didalamnya. Selain itu, menurut Persada et al. (2021) pupuk organik berbahan dasar batang pisang secara tidak langsung dapat memperbaiki struktur tanah dengan penambahan kandungan hara tanah seperti unsur hara nitrogen. Selain memperbaiki kandungan hara tanah, MOL batang pisang diketahui juga mengandung hormon, sebagaimana yang telah diteliti sebelumnya oleh Karolina (2018) sehingga dengan adanya kandungan hormon giberelin dan sitokinin dalam pupuk organik batang pisang diketahui berfungsi dalam pembelahan jaringan tanaman sehingga mampu mempercepat pertumbuhan tinggi tanaman.

Hal ini terlihat pada parameter bobot kering daun dan akar tanaman, dimana perlakuan MOL batang pisang berpengaruh nyata terhadap MOL nanas (Tabel 2), yang secara statistik rata-rata tertinggi ditunjukkan oleh perlakuan MOL batang pisang $100 \mathrm{~mL} \mathrm{~L}^{-1}$ untuk parameter berat kering daun rata-rata nilai yang ditunjukkan sebesar 12.57 g, sedangkan pada parameter berat kering akar rata-rata nilai yang ditunjukkan sebesar $9.47 \mathrm{~g}$. 
Tabel 1. Tinggi tanaman jagung manis (cm) saat umur 3 dan 7 MST

\begin{tabular}{lcccc}
\hline \multirow{2}{*}{ Perlakuan $\left(\mathrm{mL} \mathrm{L}^{-1}\right)$} & \multicolumn{3}{c}{ MOL nanas } & \multicolumn{2}{c}{ MOL batang pisang } \\
\cline { 2 - 5 } & $3 \mathrm{MST}$ & $7 \mathrm{MST}$ & $\mathrm{T}$ & $7 \mathrm{MST}$ \\
0 & 13.00 & 46.89 & 82.40 & $173.67 \mathrm{a}$ \\
100 & 16.33 & 58.00 & 84.98 & $162.01 \mathrm{~b}$ \\
150 & 9.67 & 51.78 & 85.36 & $175.33 \mathrm{a}$ \\
200 & 10.01 & 51.44 & 84.57 & $185.60 \mathrm{a}$ \\
250 & 11.00 & 58.56 & 84.66 & $178.03 \mathrm{a}$ \\
\hline $\mathrm{F}$ & tn & tn & tn & $*$ \\
\hline
\end{tabular}

Keterangan: Angka di dalam kolom yang sama yang diikuti huruf yang sama tidak berbeda nyata berdasarkan uji DMRT pada taraf 5\%, MST = minggu setelah tanam; tn = tidak nyata; $*$ = nyata

Tabel 2. Bobot kering daun dan akar tanaman jagung manis saat umur 8 MST

\begin{tabular}{lcccc}
\hline \multirow{2}{*}{ Perlakuan $\left(\mathrm{mL} \mathrm{L}^{-1}\right)$} & MOL nanas & \multicolumn{2}{c}{ MOL batang pisang } \\
\cline { 2 - 5 } & Daun & Akar & Daun & Akar \\
0 & 11.03 & 6.88 & $8.87 \mathrm{a}$ & $7.08 \mathrm{a}$ \\
100 & 11.21 & 8.15 & $12.57 \mathrm{a}$ & $9.47 \mathrm{a}$ \\
150 & 12.71 & 8.56 & $5.72 \mathrm{~b}$ & $3.08 \mathrm{~b}$ \\
200 & 13.06 & 8.77 & $5.18 \mathrm{~b}$ & $3.81 \mathrm{~b}$ \\
250 & 10.27 & 8.46 & $4.47 \mathrm{~b}$ & $2.78 \mathrm{~b}$ \\
\hline $\mathrm{F}$ & tn & tn & $*$ & $*$ \\
\hline
\end{tabular}

Keterangan: Angka di dalam kolom yang sama yang diikuti huruf yang sama tidak berbeda nyata berdasarkan uji DMRT pada taraf 5\%, MST = minggu setelah tanam; $\mathrm{tn}=$ tidak nyata; $*$ nyata

Hal lain yang juga ditemui dalam penelitian yakni pada pengamatan luas akar tanaman jagung manis (Tabel 3) menunjukkan perlakuan MOL nanas tidak berpengaruh nyata dibanding MOL batang pisang. Rata-rata luas akar tanaman tertinggi pada perlakuan MOL batang pisang ditunjukkan oleh perlakuan $250 \mathrm{~mL} \mathrm{~L} \mathrm{~L}^{-1}\left(1,134.93 \mathrm{~cm}^{-2}\right.$ $\mathrm{g}^{-1}$ ), yang berpengaruh nyata dengan perlakuan kontrol. Pengaruh nyata yang ditunjukkan oleh MOL batang pisang pada luas akar tanaman menyebabkan tanaman memperbanyak jumlah akarnya untuk mempertahankan siklus hidupnya dalam menyerap air dan hara tanah melalui aktivitas mikroorganisme di area perakaran (Tuhuteru et al., 2019). Sedangkan, pengamatan panjang akar tanaman jagung manis sama-sama berpengaruh tidak nyata.

Respon tanaman dengan pemberian MOL batang pisang yang menunjukkan pengaruh tidak nyata dengan perlakuan tanpa pemberian MOL batang pisang ini diduga karena adanya penggunaan pupuk kandang sapi

Tabel 3. Rata-rata panjang dan luas akar tanaman jagung manis pada 8 MST antara perlakuan MOL nanas dan batang pisang

\begin{tabular}{lcccc}
\hline \multirow{2}{*}{ Perlakuan $\left(\mathrm{mL} \mathrm{L}^{-1}\right)$} & \multicolumn{2}{c}{ MOL nanas } & \multicolumn{2}{c}{ MOL batang pisang } \\
\cline { 2 - 5 } & Panjang akar $(\mathrm{cm})$ & Luas akar $\left(\mathrm{cm}^{-2} \mathrm{~g}^{-1}\right)$ & Panjang akar $(\mathrm{cm})$ & Luas akar $\left(\mathrm{cm}^{-2} \mathrm{~g}^{-1}\right)$ \\
\hline 0 & 85.54 & 850.08 & 59.43 & $1,123.93 \mathrm{a}$ \\
100 & 142.99 & $1,358.08$ & 65.43 & $844.08 \mathrm{a}$ \\
150 & 99.68 & $1,242.74$ & 45.57 & $473.57 \mathrm{~b}$ \\
200 & 205.62 & $1,751.95$ & 38.98 & $546.60 \mathrm{~b}$ \\
250 & 158.43 & $1,454.10$ & 59.40 & $1,134.93 \mathrm{a}$ \\
\hline F & tn & tn & tn & $*$ \\
\hline
\end{tabular}

Keterangan: Angka di dalam kolom yang sama yang diikuti huruf yang sama tidak berbeda nyata berdasarkan uji DMRT pada taraf 5\%, MST $=$ minggu setelah tanam; $\mathrm{tn}=$ tidak nyata; $*$ = nyata 
sebagai pupuk dasar yang dapat memicu pertumbuhan dan perkembangan tanaman jagung manis. Kemampuan tanaman yang tanpa diberi perlakuan terlihat menunjukkan respon disebabkan oleh unsur hara dalam tanah mencukupi untuk pertumbuhan tanaman (Jumriani et al., 2017). Selain itu, juga dapat dipengaruhi oleh kondisi lingkungan tumbuh tanaman.

Tanaman untuk tumbuh dan berkembang dipengaruhi oleh faktor genetik dan lingkungan. Secara umum dalam teknis budidaya tanaman hampir semua unsur iklim berpengaruh terhadap produksi tanaman. Namun masingmasing mempunyai pengaruh dan peran yang berbeda terhadap berbagai aspek dalam budidaya tanaman. Secara aktual, berbagai proses fisiologi, pertumbuhan dan produksi tanaman sangat dipengaruhi oleh unsur cuaca, yaitu keadaan atmosfer dari saat ke saat selama umur tanaman, ketersediaan air (kelembaban tanah) sangat ditentukan oleh curah hujan dalam periode waktu tertentu dan disebut sebagai unsur iklim, yang pada hakikatnya adalah akumulasi dari unsur cuaca (curah hujan dari saat ke saat). Demikian juga, pertumbuhan dan produksi tanaman merupakan manivestasi akumulatif dari seluruh proses fisiologi selama fase atau periode pertumbuhan tertentu oleh sebab itu dalam pengertian yang lebih teknis dapat dinyatakan bahwa pertumbuhan dan produksi tanaman dipengaruhi oleh berbagai unsur iklim (sebagai akumulasi keadaan cuaca) selama pertumbuhan tanaman (Madia et al., 2012). Hal ini juga terlihat berpengaruh pada pengamatan terhadap luas daun dan laju pertumbuhan nisbi tanaman.

Hasil penelitian menunjukkan MOL batang pisang berpengaruh nyata pada parameter luas daun dan laju pertumbuhan nisbi (Tabel 4), sedangkan perlakuan MOL nanas menunjukkan pengaruh nyata hanya pada luas daun tanaman, yang ditunjukkan oleh perlakuan kontrol atau yang tidak diberi perlakuan MOL nanas. Sebagaimana telah disebutkan bahwa hal ini diduga dipengaruhi oleh penambahan pupuk organik yang diberikan, sehingga perbedaan yang dimunculkan tidak ada berpengaruh dengan yang berperlakuan. Pupuk kandang telah banyak dipakai dalam budidaya tanam, dengan tujuan untuk memperbanyak jumlah mikroba dan meningkatkan proses dekomposisi dalam menyediakan nutrisi untuk dapat digunakan tanaman. Keberadaan mikroba yang ada di dalam pupuk kandang berperan dalam proses aktivasi penyerapan nutrisi, meminimalisir soil-borne disease, memperlaju jalannya pengomposan, mengatur kembali karakter tanah dan memperoleh substrat yang mampu mengoptimalkan pertumbuhan tanaman (Amir dan Rosmiah, 2018).

Selanjutnya, diketahui bahwa untuk memperoleh produksi tanaman yang tinggi, tanaman budidaya diketahui harus dapat menghasilkan luas daun yang cukup untuk menyerap cahaya secara maksimal untuk pencapaian hasil berupa bobot kering maksimum sebagaimana yang ditunjukkan oleh rata-rata perlakuan MOL batang pisang $100 \mathrm{~mL} \mathrm{~L}^{-1}$. Hal ini pada akhirnya berdampak pada pertumbuhan nisbi tanaman. Kecepatan pertumbuhan tanaman atau dikenal dengan laju pertumbuhan nisbi (LPN) merupakan kapabilitas tanaman untuk memperoleh bahan kering dari proses asimilasi dalam tiap satuan bobot kering (Tuhuteru, 2017). Tabel 4 menunjukkan perlakuan konsentrasi $200 \mathrm{~mL} \mathrm{~L}^{-1} \mathrm{MOL}$ batang pisang berpengaruh nyata dengan rata-rata sebesar $0.64 \mathrm{~g} \mathrm{~g}^{-1}$ per minggu terhadap perlakuan kontrol.

\section{Perlakuan MOL tehadap Produksi}

Hasil penelitian terhadap bobot segar buah per perlakuan menunjukkan adaya pengaruh nyata pada perlakuan MOL batang pisang (Tabel 5) dibandingkan MOL nanas. Hal ini jelas bahwa komposisi hara yang diberikan dan diserap tanaman jagung manis bersifat cukup. Perlakuan pemberian konsentrasi MOL menyebabkan tanaman memperoleh unsur hara yang lebih baik, melalui hasil metabolisme dan sintesis oleh mikroorganisme (Jumriani et al., 2017). Bonggol pisang mengandung gizi yang cukup tinggi dengan komposisi yang lengkap, mengandung karbohidrat (66\%), mempunyai kandungan kadar protein $4.35 \%$, sumber mikroorganisme pengurai bahan organik atau dekomposer (Ole, 2013; Zang et al., 2013). Selain itu, Seni et al. (2013) menyatakan bahwa mikrobakteria dalam larutan mikroorganisme lokal prinsipnya menjadi generator siklus kehidupan di ruang kecil melalui cairan dari bakteri yang dimanfaatkan sebagai nutrisi bagi tanaman.

Tabel 4. Luas daun, laju pertumbuhan nisbi dan jumlah klorofil total tanaman jagung manis saat umur 8 MST

\begin{tabular}{|c|c|c|c|c|c|c|}
\hline \multirow[b]{2}{*}{ Perlakuan $\left(\mathrm{mL} \mathrm{L}^{-1}\right)$} & \multicolumn{3}{|c|}{ MOL nanas } & \multicolumn{3}{|c|}{ MOL batang pisang } \\
\hline & $\begin{array}{l}\text { Luas daun } \\
\left(\mathrm{cm}^{-2}\right)\end{array}$ & $\begin{array}{c}\mathrm{LPN}\left(\mathrm{g} \mathrm{g}^{-1}\right. \\
\text { per minggu) }\end{array}$ & $\begin{array}{l}\text { Klorofil total } \\
\left(\mathrm{mg} \mathrm{g}^{-1}\right)\end{array}$ & $\begin{array}{l}\text { Luas daun } \\
\left(\mathrm{cm}^{-2}\right)\end{array}$ & $\begin{array}{c}\mathrm{LPN}\left(\mathrm{g} \mathrm{g}^{-1}\right. \\
\text { per minggu) }\end{array}$ & $\begin{array}{c}\text { Klorofil tota } \\
\left(\mathrm{mg} \mathrm{g}^{-1}\right)\end{array}$ \\
\hline 0 & $1,191.37 \mathrm{a}$ & 0.33 & 0.04 & $714.57 b$ & $0.45 b$ & 0.10 \\
\hline 100 & $804.03 b$ & 0.51 & 0.03 & $956.70 \mathrm{a}$ & $0.57 b$ & 0.09 \\
\hline 150 & $691.17 \mathrm{c}$ & 0.39 & 0.04 & $1,499.13 a$ & $0.57 b$ & 1.02 \\
\hline 200 & $721.90 b$ & 0.49 & 0.05 & $1,069.50 \mathrm{a}$ & $0.64 \mathrm{a}$ & 0.06 \\
\hline 250 & $830.07 b$ & 0.36 & 0.04 & $2,543.65 \mathrm{a}$ & $0.61 \mathrm{a}$ & 0.05 \\
\hline $\mathrm{F}$ & * & tn & tn & $*$ & * & tn \\
\hline
\end{tabular}

Keterangan: Angka di dalam kolom yang sama yang diikuti huruf yang sama tidak berbeda nyata berdasarkan uji DMRT pada taraf 5\%, MST = minggu setelah tanam; LPN = laju pertumbuhan nisbi; $\mathrm{tn}=$ tidak nyata; $*$ = nyata 
Tabel 5. Bobot segar tongkol $(\mathrm{kg})$ jagung manis saat umur 8 MST

\begin{tabular}{lcc}
\hline Perlakuan $\left(\mathrm{mL} \mathrm{L}^{-1}\right)$ & MOL nanas & MOL batang pisang \\
\hline 0 & 0.98 & $0.75 \mathrm{~b}$ \\
100 & 1.17 & $0.88 \mathrm{~b}$ \\
150 & 1.34 & $0.66 \mathrm{~b}$ \\
200 & 1.23 & $1.86 \mathrm{a}$ \\
250 & 1.22 & $1.96 \mathrm{a}$ \\
\hline $\mathrm{F}$ & tn & $*$ \\
\hline
\end{tabular}

Keterangan: Angka di dalam kolom yang sama yang diikuti huruf yang sama tidak berbeda nyata berdasarkan uji DMRT pada taraf $5 \%$, MST $=$ minggu setelah tanam; tn = tidak nyata; $*$ nyata

\section{KESIMPULAN}

Efektifitas penggunan MOL terlihat pada penggunaan MOL batang pisang dibandingkan MOL nanas, yang ditunjukkan pada pada parameter tinggi tanaman, berat kering akar, luas daun dan laju pertumbuhan nisbi serta bobot segar tongkol jagung manis pada 8 MST.

\section{UCAPAN TERIMA KASIH}

Terima kasih tim peneliti sampaikan kepada DRPM atas support finansial yang diberikan melalui LLDIKTI wilayah XIV yang dibuktikan dengan nomor kontrak: T/27/ LL14/KS/PG/2021.

\section{DAFTAR PUSTAKA}

Amin, A.R. 2015. Mengenal budidaya mentimun melalui pemanfaatan media informasi. J. Jupiter. 16:66-71.

Amir, N., Rosmiah. 2018. Respon tanaman jagung manis (Zea mays saccharata Sturt) terhadap pupuk kompos kotoran ayam dan NPK dengan takaran berbeda. Klorofil. 13:94-98.

Inrianti, S. Tuhuteru, S. Paling. 2019. Pembuatan mikroorganisme lokal bonggol pisang pada kelompok tani Tunas Harapan Distrik Walelagama, Jayawijaya, Papua. Agrokreatif: J. Ilmiah Pengabdian Kepada Masyarakat. 5:188-194.

Jumriani, Patang, A. Mustarin. 2017. Pengaruh pemberian MOL terhadap pertumbuhan dan produksi tanamna kangkung darat (Ipomea reptans Poir). J. Pendidikan Teknologi Pertanian 3:S19-S29.

Karolina, W.M. 2018. Pengaruh pupuk organik cair bonggol pisang kepok (Musa acuminate L) terhadap pertumbuhan tanaman okra merah (Abelmoschus caillei). Tesis. Sekolah Pascasarjana. Universitas Sanata Dharma. Yogyakarta.
Kurniawan, A. 2018. Produksi MOL (mikroorganisme lokal) dengan pemanfaatan bahan-bahan organik yang ada di sekitar. J. Hexagro. 2:36-44.

Lalla, M. 2018. Potensi air cucian beras sebagai pupuk organik pada tanaman seledri (Apium graveolens L.). J. Agropolitan 5:38-43.

Madia, E., N. Irmawati, T.A. Nuri, N. Agus. 2012. Hubungan iklim dan pertumbuhan tanaman. http://mbem 25 . blogspot.com/2012/05/hubungan-iklim-danpertumbuhan-tanaman.html. [13 September 2021].

Manullang, R.R., Rusmini. 2015. Empty recemus of oil palm as source of organic fertilizer with bio-activator on soybean plants. Global J. Agric. Res. 3:1-12.

Manullang, R.R., Rusmini, Daryono. 2017. Kombinasi mikroorganisme lokal sebagai bioaktivator kompos. J. Hutan Tropis 5:259-266.

Ole, M.B.B. 2013. Penggunaan Mikroorganisme Bonggol Pisang (Musa paradisiaca) Sebagai Dekomposer Sampah Organik. Jurnal. Skripsi. Fakultas Teknobiologi, Program Studi Biologi. Universitas Atma Jaya Yogyakarta.

Persada, C., T. Nopsagiarti, Seprido. 2021. Pengaruh POC bonggol pisang terhadap pertumbuhan dan produksi tanaman jagung manis (Zea mays saccharata L.). J. Green Swarnadwipa 10:46-55.

Pradipta, R., K.P. Wicaksono, B. Guritno. 2014. Pengaruh umur panen dan pemberian berbagai dosis pupuk kalium terhadap pertumbuhan dan kualitas jagung manis (Zea mays saccharata Sturt). J. Produksi Tanaman 2:592-599.

Rahmawati, U., M. Gustina, H. Ali, R.K. Ismi. 2019. Efektivitas penambahan mikroorganisme lokal (MOL) buah maja sebagai aktivator dalam pembuatan kompos. J. Nursing Public Health 7:35-40.

Saputra, E., E. Setiono, Yudiawati. 2019. Karakteristik agronomi kacang tanah (Arachis hypogea L.) pada pemberian mikroorganisme lokal (MOL) rebung di lahan masam. J. Sains Agro 4:1-11.

Sahwan, F.L., S. Wahono, F. Suryanto. 2011. Evaluasi populasi mikroba fungsional pada pupuk organik kompos (POK) murni dan pupuk organik granul (POG) yang diperkaya dengan pupuk hayati. J. Tek. Lingkungan. 12:187-196.

Seni, I.A.Y., D.W.I. Atmaja, I.W.D., S.W.N. Sutari. 2013. Analisis kualitas larutan MOL (mikoorganisme lokal) berbasis daun gamal (Gliricidia Sepium). Agroekoteknologi Tropika 2:135-144. 
Suhastyo, A.A., I. Anas, D.A. Santosa, Y. Lestari. 2013. Studi mikrobiologi dan sifat kimia mikroorganisme lokal yang digunakan pada budidaya padi metode SRI (System of Rice Intensification). Sainteks. 10: 29-39.

Susi, N., S. Surtinah, M. Rizal. 2018. Pengujian kandungan unsur hara organik cair (POC) limbah kulit nenas. J. Ilmiah Pertanian 14:46-51.

Tuhuteru, S. 2017. Pengaruh plant growth promoting rhizobacteria (PGPR) terhadap pertumbuhan dan hasil tiga kultivar bawang merah di lahan pasir pantai. Tesis. Sekolah Pascasarjana. Universitas Gadjah Mada. Yogyakarta.

Tuhuteru, S. 2018. Efektivitas hara makro dan mikro terhadap pertumbuhan tanaman jagung (Zea mays L.). J. Agroekotek. 10:65-73.
Tuhuteru, S., E. Sulistyaningsih, A. Wibowo. 2019. Aplikasi plant growth promoting rhizobacteria dalam meningkatkan produktivitas bawang merah di lahan pasir pantai. J. Agron. Indonesia 47:53-60.

Utama, C.S., B. Sulistiyanto B., B. Setiani. 2013. Profil mikrobiologis pollard yang difermentasikan dengan ekstrak limbah pasar sayur pada lama peram yang berbeda. J. Agripet. 13:26-30.

Wahyudi, H., A. Kasry, I.S. Purwaningsih. 2012. Pemanfaatan limbah cair pabrik kelapa sawit untuk memenuhi kebutuhan unsur hara dalam budidaya tanaman jagung (Zea mays L.). J. Ilmu Lingkungan. 5:94-102.

Zhang, C., J. Li, C. Liu, X. Liu, J. Wang, S. Li, G. Fan, L. Zhang. 2013. Alkaline pretreatment for enhancement of biogas production from banana stem and swine manure by anaerobic codigestion. Biores. Tech. 149:353-358. 